Correspondence

Xiuzhu Dong

dongxz@im.ac.cn

\section{Proteiniclasticum ruminis gen. nov., sp. nov., a strictly anaerobic proteolytic bacterium isolated from yak rumen}

\author{
Kegui Zhang, ${ }^{1,2}$ Lei Song ${ }^{1}$ and Xiuzhu Dong ${ }^{1}$
${ }^{1}$ State Key Laboratory of Microbial Resources, Institute of Microbiology, Chinese Academy of Sciences, Beijing 100101, PR China
${ }^{2}$ Graduate University, Chinese Academy of Sciences, Beijing 100049, PR China

\begin{abstract}
Two strictly anaerobic, proteolytic bacterial strains, designated strain D3RC-2 ${ }^{\top}$ and D3RC-3r, were isolated from a cellulose-degrading mixed culture enriched from yak rumen content. The strains were Gram-stain negative and non-spore-forming with cell sizes of $0.5-0.8 \times 0.6-2.0 \mu \mathrm{m}$. The temperature range for growth was $24-46{ }^{\circ} \mathrm{C}$ (optimum $38-39{ }^{\circ} \mathrm{C}$ ) and the $\mathrm{pH}$ range was between 5.6 and 8.7 (optimum 7.0-7.3). Both strains used soya peptone, tryptone, Lphenylalanine, L-leucine, L-methionine, L-serine, L-valine, L-threonine and L-histidine as carbon and nitrogen sources, but did not use any of the saccharides tested. The major fermentation products from PY medium were acetate, propionate and iso-butyrate. The DNA G + C contents of strains D3RC-2 ${ }^{\top}$ and D3RC-3r were $41.0 \pm 0.1 \mathrm{~mol} \%$ and $41.3 \pm 0.1 \mathrm{~mol} \%$ (HPLC),

respectively. Phylogenetic analysis based on 16S rRNA gene sequences revealed that the two strains represented a new phyletic sublineage within the family Clostridiaceae, with $<93.8 \% 16 \mathrm{~S}$ rRNA gene sequence similarity to recognized species. On the basis of the phenotypic, genotypic and physiological evidence, strains D3RC- $2^{\top}$ and D3RC-3r are proposed as representing a novel species of a new genus, for which the name Proteiniclasticum ruminis gen. nov., sp. nov. is proposed. The type strain of the type species is D3RC-2 ${ }^{\top}\left(=\right.$ AS $\left.1.5057^{\top}=J C M 14817^{\top}\right)$.
\end{abstract}

Yak (Bos grunniens) are ruminants that feed exclusively on grasses and live mainly on the Qinghai-Tibetan Plateau, China, at a height of $3000 \mathrm{~m}$ above sea level. Previous studies based on an uncultured approach (An et al., 2005) in our laboratory have indicated that more than half of the microbes in yak rumen belong to as yet uncultured groups. The strains all showed $<90 \% 16 \mathrm{~S}$ rRNA gene sequence similarity levels with recognized species and $10.8 \%$ of the sequences retrieved were related to known rumen fibrolytic bacteria. By using filter paper as the sole carbon source, a cellulose-degrading mixed culture enriched from yak rumen content was obtained. A few fibrolytic and nonfibrolytic bacterial strains were isolated from the mixed culture. In this paper, two proteolytic bacterial strains isolated from yak rumen are described.

Strains D3RC-2 ${ }^{\mathrm{T}}$ and D3RC-3r were isolated from a fibrolytic mixed culture enriched from yak rumen. The yak rumen content was inoculated into a modified basal

The GenBank accession numbers for the $16 \mathrm{~S}$ rRNA sequences of Proteiniclasticum ruminis strains D3RC- $2^{\top}$ and D3RC-3r are D0852338 and FJ527031, respectively.

An extended phylogenetic tree and a table detailing the cellular fatty acid content of strain D3RC- $2^{\top}$ are available with the online version of this paper. medium (Bryant \& Burkey, 1953; Hungate, 1966) with filter paper as the sole carbon source and grown under a gas phase of $\mathrm{N}_{2} / \mathrm{CO}_{2}(80: 20)$. A fibrolytic mixed culture was obtained by subculturing the enrichment in the same medium. By means of serial dilution in peptone-yeast extract-glucose medium (PYG, Holdeman et al., 1977) and the Hungate roll-tube technique (Hungate, 1969), single colonies were picked and transferred to the same medium. The roll-tube procedure was repeated several times before strains D3RC$2^{\mathrm{T}}$ and D3RC-3r were obtained. The purity of the isolates was examined by light microscopy. All inoculations and transfers were performed with syringes and needles and the cultures were incubated at $39{ }^{\circ} \mathrm{C}$ unless otherwise indicated.

Cell morphology was examined under a light microscope (BH-2; Olympus) and an electron microscope (H-600A; Hitachi). Gram staining was carried out according to Johnson et al. (1995). For electron microscopy studies, bacterial cells were negatively stained with uranyl acetate. Spore formation was examined by phase-contrast microscopy under different growth conditions and at different growth phases as well as by heat treatment in a water bath at $85{ }^{\circ} \mathrm{C}$ for $10 \mathrm{~min}$ in growth medium.

Cells were Gram-stain negative, rod-shaped (with sizes of $0.5-0.8 \times 0.6-2.0 \mu \mathrm{m}$ ), occurred singly or in pairs and were 
non-motile (Fig. 1a). The Gram-negative cell-wall structure was also confirmed by the $\mathrm{KOH}$-lysis test (Smibert \& Krieg, 1994) and by means of an electron micrograph of an ultrathin section (Fig. 1b). Spores were never observed under various growth conditions or at different growth phases. The novel strains were unable to survive after incubation at $85{ }^{\circ} \mathrm{C}$ for $10 \mathrm{~min}$.

Growth was determined by monitoring $\mathrm{OD}_{600}$ of the cultures in PY medium at $39{ }^{\circ} \mathrm{C}$. The strains were strictly anaerobic, no growth occurred when the cultures were exposed to air. A generation time of $1.8 \mathrm{~h}$ was determined for strain D3RC-2 ${ }^{\mathrm{T}}$ by monitoring the culture $\mathrm{OD}_{600}$ at $30 \mathrm{~min}$ intervals up to $24 \mathrm{~h}$. The temperature profile of strain D3RC-2 ${ }^{\mathrm{T}}$ was determined in a water bath from 20 to $50{ }^{\circ} \mathrm{C}$ at $1{ }^{\circ} \mathrm{C}$ intervals. Growth was observed between $24{ }^{\circ} \mathrm{C}$ and $46{ }^{\circ} \mathrm{C}$, with optimal growth at $38-39{ }^{\circ} \mathrm{C}$ ( $\mathrm{pH}$ 7.0). The $\mathrm{pH}$ range for growth was $\mathrm{pH}$ 5.6-8.7 with optimal growth around $\mathrm{pH} 7.0-7.3$ as determined in PY
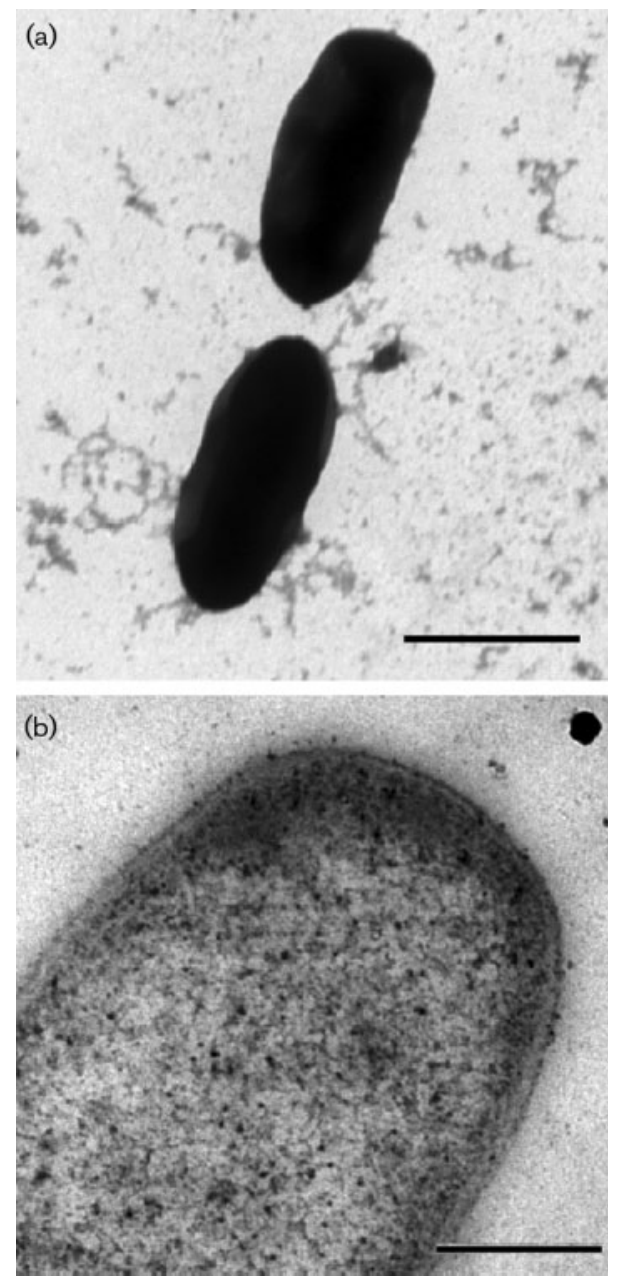

Fig. 1. Electron micrographs of cells of strain $D 3 R C-2^{\top}$. (a) Negatively stained cells, Bar, $1.0 \mu \mathrm{m}$. (b) Ultrathin section of a cell. Bar, $0.2 \mu \mathrm{m}$. broth at various $\mathrm{pH}$ values adjusted by the addition of $\mathrm{Na}_{2} \mathrm{HPO}_{4}$ and $\mathrm{NaH}_{2} \mathrm{PO}_{4}$.

Substrate utilization was tested by growing the two novel strains in basal medium containing each of the substrates as follows: $1 \%(\mathrm{w} / \mathrm{v})$ cellobiose, glucose, xylose, arabinose, maltose, mannose, trehalose, salicin, lactose, melezitose, raffinose, rhamnose, mannitol and glycerol, $0.5 \%(\mathrm{w} / \mathrm{v})$ soya peptone and tryptone, and $0.2 \%(\mathrm{w} / \mathrm{v})$ L-alanine, Lcysteine, L-aspartic acid, L-glutamic acid, L-phenylalanine, L-glycine, L-histidine, L-isoleucine, L-lysine, L-leucine, Lmethionine, L-asparagine, L-proline, L-arginine, serine, Lthreonine, valine and tryptophan. Substrate utilization was also detected using the API $50 \mathrm{CH}$ system (bioMérieux) according to the manufacturer's instructions. Other physiological characteristics were determined according to Holdeman et al. (1977). The short-chain fatty acids were analysed by GC (GC-14B, Shimadzu) according to Chen \& Dong (2004).

The two novel strains exhibited almost identical physiological and biochemical profiles using both conventional methods as well as the API $50 \mathrm{CH}$ system. The results indicated that the two isolates represented a single species. Strain D3RC-2 $2^{\mathrm{T}}$ utilized the following compounds: soya peptone, tryptone, L-phenylalanine, L-leucine, L-methionine, L-serine, L-valine, L-threonine and L-histidine. None of the carbohydrates or alcohols tested were used. The major fermentation products from PY medium were acetate, propionate and iso-butyrate. Propionate, isobutyrate and acetate were produced from L-methionine and L-leucine, L-threonine and L-serine, and L-histidine, respectively. Other physiological characteristics are listed in the species description below.

Cellular fatty acids were extracted, methylated and analysed using the standard MIDI (Microbial Identification) system (Miller, 1982; Sasser, 1990). The cellular fatty acids of strain D3RC-2 ${ }^{\mathrm{T}}$ comprised mainly iso-branched fatty acids, predominantly iso- $\mathrm{C}_{14: 0}(19.4 \%)$, iso- $\mathrm{C}_{13: 0}(19.2 \%)$, iso$\mathrm{C}_{15: 0}(15.2 \%), \mathrm{C}_{14: 0}(15.1 \%)$, anteiso- $\mathrm{C}_{13: 0}(10.0 \%)$ and anteiso- $\mathrm{C}_{15: 0}(9.2 \%)$ (see Supplementary Table S1 in IJSEM Online).

The genomic DNA was extracted and purified according to Marmur (1961). The G $+C$ contents of the genomic DNA of strains D3RC- $2^{\mathrm{T}}$ and D3RC-3r were determined to be $41.0 \pm 0.1 \mathrm{~mol} \%$ and $41.3 \pm 0.1 \mathrm{~mol} \%$, respectively, by using HPLC (Mesbah et al., 1989) with the modification of Lee et al. (2005). Both strains were subjected to DNADNA hybridization analysis and the DNA relatedness value of $96 \%$ confirmed that the two strains represented a single species.

The 16S rRNA genes were amplified using the bacterial universal primers 27F and 1541R (Weisburg et al., 1991). The purified PCR products of approximately $1.5 \mathrm{~kb}$ in length were cloned to Escherichia coli $\mathrm{DH} 5 \alpha$ and sequenced by the Sangon Biological Engineering Technology Service, Shanghai, China. The 16S rRNA gene sequences were 


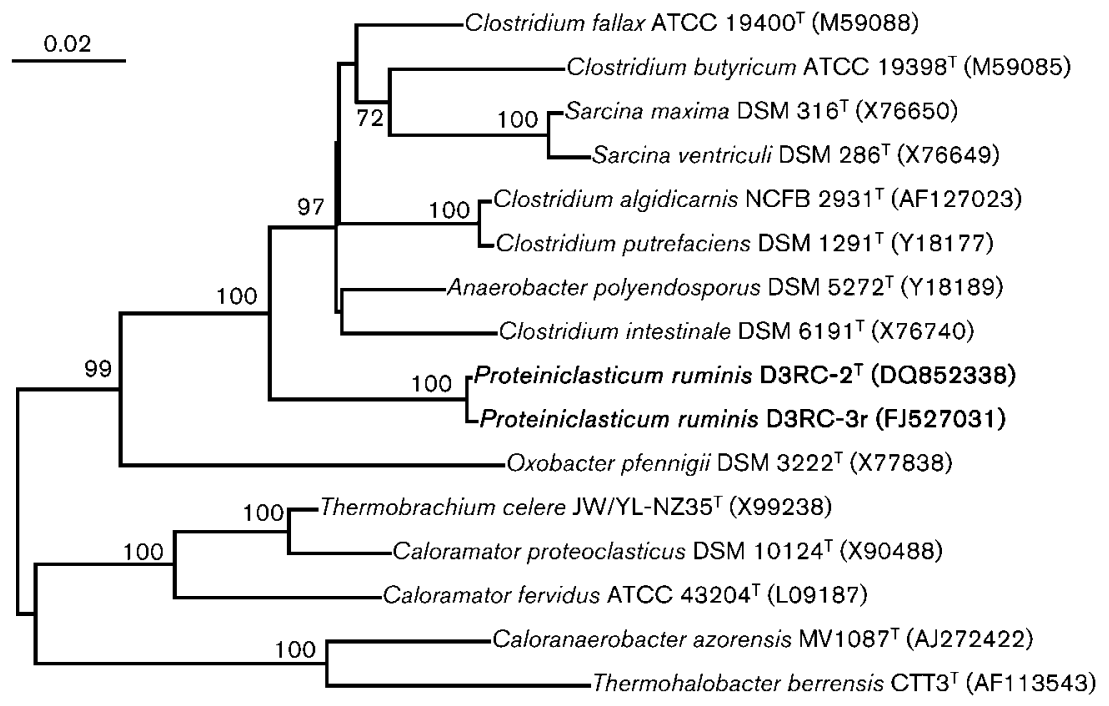

Fig. 2. Unrooted neighbour-joining phylogenetic tree showing strains D3RC-2 ${ }^{\top}$, D3RC-3r and related genera of the family Clostridiaceae based on 16S rRNA gene sequence comparisons. Numbers at nodes represent the levels of bootstrap support (\%) based on a neighbour-joining analysis of 1000 resampled datasets. GenBank accession numbers are given in parentheses. Bar, $2 \%$ sequence divergence.

submitted to GenBank to search for the similar sequences using the BLAST algorithm. The 16S rRNA sequences of strains $\mathrm{D} 3 \mathrm{RC}-2^{\mathrm{T}}$ and reference strains retrieved from GenBank were aligned using the CLUSTAL_X program (v1.83) (Thompson et al., 1997). Phylogenetic trees were constructed using the neighbour-joining, UPGMA, minimum-evolution and maximum-parsimony methods implemented in the MEGA3 program (Kumar et al., 2001). The stability of the trees was evaluated by bootstrap analysis of 1000 datasets (Felsenstein, 1985). To ascertain the phylogenetic position of the new isolates, the complete $16 \mathrm{~S}$ rRNA gene sequences were compared with the most similar sequences retrieved from GenBank. On the basis of a consensus $1354 \mathrm{bp}$ of $16 \mathrm{~S}$ rRNA gene sequences, an unrooted phylogenetic tree revealed that the two strains represented a new phyletic sublineage within the family Clostridiaceae, with $<93.8 \%$ 16S rRNA gene sequence similarity to recognized species (Fig. 2). The phylogenetic position of the two strains was also confirmed by an additional phylogenetic tree which included all of the recognized species of the genus Clostridium as well as species of other genera of the family Clostridiaceae (see Supplementary Fig. S1 in IJSEM Online). The large sequence divergence indicated that the novel strains isolated in this study represented a new genus in the family Clostridiaceae.

The two novel strains also showed distinct phenotypic features which enabled them to be distinguished from all of the genera already assigned to the family Clostridiaceae (see Table 1). They did not utilize carbohydrates and so differed from members of the genera Alkaliphilus, Anaerobacter, Anoxynatronum, Caloramator, Caloranaerobacter, Caminicella, Oxobacter, Sarcina, Thermobrachium and Thermohalobacter. The novel strains could be differentiated from members of the

Table 1. Characteristics that differentiate strain $D 3 R C-2^{\top}$ from recognized genera of the family Clostridiaceae

Taxa: 1, strain D3RC-2 ${ }^{\mathrm{T}}$; 2, Alkaliphilus (Takai et al., 2001; Cao et al., 2003); 3, Anaerobacter (Duda et al., 1987); 4, Anoxynatronum (Garnova et al., 2003); 5, Caloramator (Patel et al., 1987; Christostomos et al., 1996); 6, Caloranaerobacter (Wery et al., 2001); 7, Caminicella (Alain et al., 2002); 8, Clostridium (Hippe et al., 1992); 9, Natronincola (Zhilina et al., 1998); 10, Oxobacter (Krumholz \& Bryant, 1985); 11, Sarcina (Canale-Parole, 1986); 12, Thermohalobacter (Cayol et al., 2000); 13, Thermobrachium (Engle et al., 1996); 14, Tindallia (Kevbrin et al., 1998). +, Positive; -, negative; + /-, variable; $\mathrm{w}$, weakly positive.

\begin{tabular}{|c|c|c|c|c|c|c|c|c|c|c|c|c|c|c|}
\hline Characteristic & 1 & 2 & 3 & 4 & 5 & 6 & 7 & 8 & 9 & 10 & 11 & 12 & 13 & 14 \\
\hline Cell motility & - & + & - & + & $+1-$ & + & + & + & + & + & - & + & + & + \\
\hline Gram reaction & - & + & + & + & - & - & - & $+1-$ & + & + & + & - & + & + \\
\hline $\mathrm{NaCl}$ requirement & - & - & - & + & - & + & + & $+1-$ & + & - & - & + & - & + \\
\hline \multicolumn{15}{|l|}{ Substrates utilized: } \\
\hline Carbohydrates & - & + & + & + & + & + & + & $+1-$ & - & + & + & + & + & - \\
\hline Amino acids & + & - & - & + & $+1-$ & + & w & $+1-$ & + & - & - & - & + & - \\
\hline DNA G $+C$ content $(\mathrm{mol} \%)$ & 41.0 & $30-36$ & 29.0 & 48.4 & $25.6-39.0$ & 27.0 & 24.2 & $21-54$ & 31.9 & 38.0 & $28.6-30.6$ & 33.0 & 31.0 & $26.9-40$ \\
\hline
\end{tabular}


genus Anaerobacter by the latter's ability to form up to five endospores per cell. The novel strains differed from members of the genus Clostridium by the latter's motility and spore formation. The two novel strains were Gram-staining negative and non-spore-forming which differentiated them from members of the genera Natronincola and Tindallia.

On the basis of the distant phylogenetic relationship with related taxa, unique chemotaxonomic characteristics and the physiological and biochemical traits described above, it is evident that strains D3RC- $2^{\mathrm{T}}$ and D3RC-3r represent a novel species of a new genus of the family Clostridiaceae, for which the name Proteiniclasticum ruminis gen. nov., sp. nov. is proposed.

\section{Description of Proteiniclasticum gen. nov.}

Proteiniclasticum [Pro.te.i.ni.cla.sti'cum. N.L. neut. n. proteinum protein; N.L adj. clasticus (from Gr. adj. klastos) breaking; N.L. neut. n. Proteiniclasticum a bacterium able to digest proteins].

Cells are Gram-negative, rod-shaped, non-spore-forming and non-motile. Obligately anaerobic. Mesophilic and neutrophilic. Proteolytic. Do not utilize carbohydrates. Soya peptone, tryptone and amino acids are used as carbon and nitrogen sources. The major fermentation products from PY medium are acetate, propionate and iso-butyrate. The cellular fatty acids mainly comprise isobranched fatty acids. The type species is Proteiniclasticum ruminis.

\section{Description of Proteiniclasticum ruminis sp. nov.}

Proteiniclasticum ruminis (ru.mi'nis. L. neut. gen. n. ruminis of the rumen).

Displays the following properties in addition to those given in the genus description. Cells are $0.6-2.0 \mu \mathrm{m}$ in length and $0.5-0.8 \mu \mathrm{m}$ in width. Spores are not observed. The temperature range for growth is $24-46{ }^{\circ} \mathrm{C}$, optimal growth occurs at $38-39^{\circ} \mathrm{C}$. The $\mathrm{pH}$ range for growth is 5.6-8.7, optimum growth occurs at $\mathrm{pH} 7.0-7.3$. The generation time is $1.8 \mathrm{~h}$ in PY medium at $39^{\circ} \mathrm{C}$. Utilizes soya peptone, tryptone, L-phenylalanine, L-leucine, L-methionine, Lserine, L-valine, L-threonine and L-histidine, but not cellobiose, glucose, xylose, arabinose, maltose, salicin, mannitol, lactose, glycerol, melezitose, raffinose, rhamnose, L-alanine, L-cysteine, L-aspartic acid, L-glutamic acid, Lglycine, L-isoleucine, L-lysine, L-asparagine, L-proline, Lglutamine, L-arginine or L-tryptophan. Propionate is produced from L-methionine and L-leucine. Iso-butyrate is produced from L-threonine. Liquefies gelatin but does not reduce nitrate. Aesculin is hydrolysed. Does not produce $\mathrm{H}_{2} \mathrm{~S}$ or indole. The Voges-Proskauer test is negative. Milk is curdled. The cellular fatty acids of strain D $3 R C-2^{\mathrm{T}}$ are mainly composed of iso-branched fatty acids, predominantly iso- $\mathrm{C}_{14: 0}$, iso- $\mathrm{C}_{13: 0}$, iso- $\mathrm{C}_{15: 0}, \mathrm{C}_{14: 0}$, anteiso- $\mathrm{C}_{13: 0}$ and anteiso- $\mathrm{C}_{15: 0}$. The $\mathrm{G}+\mathrm{C}$ content of the genomic DNA is $41.0 \pm 0.1 \mathrm{~mol} \%$.
The type strain, D3RC- $2^{\mathrm{T}}\left(=\mathrm{AS} 1.5057^{\mathrm{T}}=\mathrm{JCM} 14817^{\mathrm{T}}\right)$, was isolated from yak rumen.

\section{Acknowledgements}

This study has been supported by National Basic Research Program of China (2004CB719602).

\section{References}

Alain, K., Pignet, P., Zbinden, M., Quillevere, M., Duchiron, F., Donval, J. P., Lesongeur, F., Raguenes, G., Crassous, P. \& other authors (2002). Caminicella sporogenes gen. nov., sp. nov., a novel thermophilic spore-forming bacterium isolated from an East-Pacific Rise hydrothermal vent. Int J Syst Evol Microbiol 52, 1621-1628.

An, D., Dong, X. \& Dong, Z. (2005). Prokaryote diversity in the rumen of yak (Bos grunniens) and Jinnan cattle (Bos taurus) estimated by $16 \mathrm{~S}$ rRNA homology analyses. Anaerobe 11, 207-215.

Bryant, M. P. \& Burkey, L. A. (1953). Cultural methods and some characteristics of some of the more numerous groups of bacteria in the bovine rumen. J Dairy Sci 36, 205-217.

Canale-Parole, E. (1986). Genus Sarcina Goodsir 1842. In Bergey's Manual of Systematic Bacteriology, vol. 2, pp. 1100-1103. Edited by P. H. A. Sneath, N. S. Mair, M. E. Sharpe \& J. G. Holt. Baltimore: Williams and Wilkins.

Cao, X., Liu, X. \& Dong, X. (2003). Alkaliphilus crotonatoxidans sp. nov., a strictly anaerobic, crotonate-dismutating bacterium isolated from a methanogenic environment. Int J Syst Evol Microbiol 53, 971975.

Cayol, J.-L., Ducerf, S., Patel, B. K. C., Garcia, J.-L., Thomas, P. \& Ollivier, B. (2000). Thermohalobacter berrensis gen. nov., sp. nov., a thermophilic, strictly halophilic bacterium from a solar saltern. Int $J$ Syst Evol Microbiol 50, 559-564.

Chen, S. \& Dong, X. (2004). Acetanaerobacterium elongatum gen. nov., sp. nov., from paper mill waste water. Int J Syst Evol Microbiol 54, 2257-2262.

Christostomos, S., Patel, B. K. C., Dwivedi, P. P. \& Denman, S. E. (1996). Caloramator indicus sp. nov., a new thermophilic anaerobic bacterium isolated from the deep-seated nonvolcanically heated waters of an Indian artesian aquifer. Int J Syst Bacteriol 46, 497-501.

Duda, V. I., Lebedinsky, A. V., Mushegjan, M. S. \& Mitjushina, L. L. (1987). A new anaerobic bacterium, forming up to five endospores per cell - Anaerobacter polyendosporus gen. et spec. nov. Arch Microbiol 148, 121-127.

Engle, M., Li, Y., Rainey, F., DeBlois, S., Mai, V., Reichert, A., Mayer, F., Messner, P. \& Wiegel, J. (1996). Thermobrachium celere gen. nov., sp. nov., a rapidly growing thermophilic, alkalitolerant, and proteolytic obligate anaerobe. Int J Syst Bacteriol 46, 1025-1033.

Felsenstein, J. (1985). Confidence limits on phylogenies: an approach using the bootstrap. Evolution 39, 783-791.

Garnova, E. S., Zhilina, T. N., Tourova, T. P. \& Lysenko, A. M. (2003). Anoxynatronum sibiricum gen. nov., sp. nov. alkaliphilic saccharolytic anaerobe from cellulolytic community of Nizhnee Beloe (Transbaikal region). Extremophiles 7, 213-220.

Hippe, H., Andreesen, J. R. \& Gottschalk, G. (1992). The genus Clostridium - nonmedical. In The Prokaryotes, 2nd edn, vol. 2, pp. 1800-1866. Edited by A. Balows, H. G. Trüper, M. Dworkin, W. Harder \& K. H. Schleifer. New York: Springer.

Holdeman, L. V., Cato, E. P. \& Moore, M. E. C. (1977). Anaerobe Laboratory Manual, 4th edn. Blacksburg, VA: Virginia Polytechnic Institute \& State University. 
Hungate, R. E. (1966). The Rumen and its Microbes. New York: Academic Press.

Hungate, R. E. (1969). A roll tube method for cultivation of strict anaerobes. Methods Microbiol 3B, 117-132.

Johnson, M. J., Thatcher, E. \& Cox, M. E. (1995). Techniques for controlling variability in gram staining of obligate anaerobes. J Clin Microbiol 33, 755-758.

Kevbrin, V. V., Zhilina, T. N., Rainey, F. A. \& Zavarzin, G. A. (1998). Tindallia magadii gen. nov., sp. nov.: an alkaliphilic anaerobic ammonifier from soda lake deposits. Curr Microbiol 37, 94-100.

Krumholz, L. R. \& Bryant, M. P. (1985). Clostridium pfennigii sp. nov. uses methoxyl groups of monobenzenoids and produces butyrate. Int J Syst Bacteriol 35, 454-456.

Kumar, S., Tamura, K., Jakobsen, I. B. \& Nei, M. (2001). MEGA2: molecular evolutionary genetics analysis software. Bioinformatics 17 , 1244-1245.

Lee, Y.-J., Wagner, I. D., Brice, M. E., Kevbrin, V. V., Mills, G. L., Romanek, C. S. \& Wiegel, J. (2005). Thermosediminibacter oceani gen. nov., sp. nov. and Thermosediminibacter litoriperuensis sp. nov., new anaerobic thermophilic bacteria isolated from Peru Margin. Extremophiles 9, 375-383.

Marmur, J. (1961). A procedure for the isolation of deoxyribonucleic acid from microorganisms. J Mol Biol 3, 208-218.

Mesbah, M., Premachandran, U. \& Whitman, W. B. (1989). Precise measurement of the $\mathrm{G}+\mathrm{C}$ content of deoxyribonucleic acid by highperformance liquid chromatography. Int J Syst Bacteriol 39, 159-167.

Miller, L. T. (1982). Single derivatization method for routine analysis of bacterial whole-cell fatty acid methyl esters, including hydroxyl acids. J Clin Microbiol 16, 584-586.
Patel, B. K. C., Monk, C., Littleworth, H., Morgan, H. W. \& Daniel, R. M. (1987). Clostridium fervidus sp. nov., a new chemoorganotrophic acetogenic thermophile. Int J Syst Bacteriol 37, 123-126.

Sasser, M. (1990). Identification of bacteria by gas chromatography of cellular fatty acids, MIDI Technical Note 101. Newark, DE: MIDI Inc.

Smibert, R. M. \& Krieg, N. R. (1994). Phenotypic characterization. In Methods for General and Molecular Bacteriology, pp. 607-654. Edited by P. Gerhardt, R. G. E. Murray, W. A. Wood \& N. R. Krieg. Washington, DC: American Society for Microbiology.

Takai, K., Moser, D. P., Onstott, T. C., Spoelstra, N., Pfiffner, S. M., Dohnalkova, A. \& Fredrickson, J. K. (2001). Alkaliphilus transvaalensis gen. nov., sp. nov., an extremely alkaliphilic bacterium isolated from a deep South African gold mine. Int J Syst Evol Microbiol 51, 1245-1256.

Thompson, J. D., Gibson, T. J., Plewniak, F., Jeanmougin, F. \& Higgins, D. G. (1997). The CLUSTAL_X windows interface: flexible strategies for multiple sequence alignment aided by quality analysis tools. Nucleic Acids Res 25, 4876-4882.

Weisburg, W. G., Barns, S. M., Pelletier, D. A. \& Lane, D. J. (1991). 16S ribosomal DNA amplification for phylogenetic study. J Bacteriol 173, 697-703.

Wery, N., Moricet, J.-M., Cueff, V., Jean, J., Pignet, P., Lesongeur, F., Cambon-Bonavita, M.-A. \& Barbier, G. (2001). Caloranaerobacter azorensis gen. nov., sp. nov., an anaerobic thermophilic bacterium isolated from a deep-sea hydrothermal vent. Int J Syst Evol Microbiol 51, 1789-1796.

Zhilina, T. N., Detkova, E. N., Rainey, F. A., Osipov, G. A., Lysenko, A. M., Kostrikina, N. A. \& Zavarzin, G. A. (1998). Natronoincola histidinovorans gen. nov., sp. nov., a new alkaliphilic acetogenic anaerobe. Curr Microbiol 37, 177-185. 